7. Фесикова, О. В. Преображение человека и природы в современной философии // Вестник научной сессии факультета философии и психологии Воронежского государственного университета / отв. ред. И. И. Борисов. - Воронеж, 2012. - Вып. 13. - С. 165-168. - Библиогр.: с. 168 (8 назв.).

8. Фесикова, О.В. Жизнь, экология и человек // Актуальные проблемы международных отношений в условиях формирования мультиполярного мира : сборник научных статей 3 Международной научно-практической конференции, Курск, 17 декабря 2015 года / под ред.: Л. В. Бычковой, В. М. Кузьминой. - Курск, 2015. - С. 164-168. - еLIBRARY.

9. Фесикова, О.В. Философский аспект экологии [Текст] // Научный альманах. - 2016. - № 3-4 (17). - C. 162-165. - Режим доступа: http://ucom.ru/doc/na.2016.03.04.162.pdf. - eLIBRARY.

\title{
Чиркова П.Р. \\ Философские проблемы в романе Ф.М. Достоевского «Преступление и наказание»
}

Московский художественно-промышленный институт

(Россия, Москва)

doi: $10.18411 / \mathrm{j}-06-2021-119$

\section{Аннотация}

В статье проводится философский анализ романа Ф.М. Достоевского «Преступление и наказание». Выделяются онтологические, гносеологические и аксиологические проблемы, поднятые мыслителем. Исследуются выводы писателя и даётся рекомендация к изучению книги.

Ключевые слова: Ф.М. Достоевский, роман «Преступление и наказание», онтология, гносеология, аксиология, философия.

\section{Abstract}

The article provides a philosophical analysis of the novel by F.M. Dostoevsky's "Crime and Punishment". Ontological, epistemological and axiological problems raised by the thinker are highlighted. The conclusions of the writer are examined and a recommendation for the study of the book is given.

Keywords: F. M. Dostoevsky, the novel "Crime and Punishment", ontology, epistemology, axiology, philosophy.

Социально-психологический и социально-философский роман Федора Михайловича является поводом для размышления о вопросах, которые интересны каждому человеку. В книге поднимаются проблемы онтологии, гносеологии, аксиологии. Главная проблема онтологического характера, которую можно увидеть в романе - проблема существования Бога. Русский мыслитель выделяет два варианта жизненного пути, по которому может следовать человек. Первый путь человекобожества. Данный путь предполагает абсолютную свободу человека. Жизнь такого человека строится на отвержении любых авторитетов, в том числе авторитете и признании самого Бога. Такой человек верит в свои безграничные возможности, а также в право делать абсолютно все, что ему заблагорассудится. Такой человек пытается сам стать Богом. Достоевский уверен, что подобный путь носит опасный и губительный характер для самого человека и людей, которые его окружают. Человек, который выбирает данный путь следования, неизменно терпит крах. Второй путь - путь богочеловека. Данный путь предполагает путь следования Богу, стремление человека к Богу, которое он выражает в своих действиях и поступках. Данный путь будет самым правильным и верным для каждого человека. Он направлен на спасение [4, с. 237].

Оба эти пути можно увидеть в романе на примере жизни главного героя. По первому пути Раскольников следует, когда делает для себя вывод,что может принимать решение по поводу того, кому стоит жить, а кому - нет. Он делает вывод, что жизнь старухи-процентщицы значит «...Не более как жизнь вши, таракана, да и того 
не стоит...» [2]. Он уверен, что имеет право принимать такое решение вместо Бога, видит себя Богом. И, как мы видим, Достоевский показывает, насколько разрушительно сказывается путь «человекобожества», выбранный героем не только на жизни другого человека (старухи), но и на нем самом. Его внутренний дискомфорт, постепенно переходящий в экзистенциальную внутреннюю агонию, сказывается на разрушении его жизненных представлений, смысла, ценностной системы.

На второй путь - «путь богочеловека» Раскольникову поможет встать позднее Сонечка Мармеладова. В их диалогах можно увидеть внутреннюю борьбу героя, которому сложно принять тот факт, что Бог не только есть, но и может помочь. Сонечка дарит ему крест, с которого начинается пока еще неясный путь к Богу. Герой не верит в Бога. Ее зарождение ждет героя впереди. Ф.М. Достоевский создаёт образ реализации идеи сверхчеловека Ф. Ницше и противопоставляет ему образ человека, прислушивающегося к Богу, живущего в ладу с ним. Существование Бога как высшей духовной субстанции, необходимость обращения к нему - ведущая проблема романа. Следует отметить, что изначально роман должен был оканчиваться строками: «Неисповедимы пути, которыми находит Бог человека» [3]

Вторая онтологическая проблема, поднятая в романе - проблема взаимоотношения между индивидом и обществом. Совершив преступление, Раскольников начинает ощущать потерю своей связи с другими членами социума, отдаляется от них. Но поскольку человек - существо биосоциальное, каждый, в той или иной степени, все равно испытывает потребность в общении, желании поделиться, почувствовать себя не так одиноко. Это приводит его к решимости начать общение с Соней Мармеладовой. Будет логично предположить, что в дальнейшем, когда герой поймет позицию героини, осознает себя как часть социума, а также как человека, следующий пути богочеловека, его конфликт с обществом, связанный в отступлении от христианских ценностей, сможет получить своё разрешение. Устранив враждебное отношение к другим людям, свое антихристианское настроение, герой гармонизирует свои взаимоотношения с социумом.

Одна изглавных проблем гносеологического характера, присутствующая в романе - внутренние заблуждения героя, поиск истины, которая могла бы указать верный путь. Изначально герой уже был внутренне запутан, блуждал в«темноте» своего сознания. В конце романа он обретает христианское смирение, знакомится с Евангелием, начинает взращивать в себе любовь к ближнему. Тем самым, герой обретает не только истину о том, как нужножить, но и смысл жизни, который также был им утерян.

Большое место в романе отводится аксиологическим проблемам, то есть вопросам о том, что есть ценность, как должно жить человеку. На наш взгляд, ключевой здесь является проблема смысла жизни. Федор Михайлович желает продемонстрировать, что именно в сложных жизненных ситуациях, через которые герои проходят, может раскрыться природа человека, а также его предназначение. Герой не имел никакого смысла жизни. Это можно увидеть в его скитаниях, построениях ложных теорий, наличии множества внутренних противоречий. В конце романа он обретает смысл жизни в Боге, любви кдругому человеку (Соне), а затем и к каждому человеку. Этот новый смысл будет той самой путеводной звездой, ради которой герой столько прошел и выстрадал. Безусловно, можно было обойтись и без убийства, чтобы обрести этот смысл. Но герой не знал об этом.

Другая аксиологическая проблема - проблема дихотомии добра и зла как важных компонентов мировоззрения человека. Понятия добра и зла рассматриваются не в качестве абстрактных. Писательл связывает их непосредственно с Богом. К добру относится все, что связано с Богом, «единение с Богом». Соответственно, зло отречение человека от Бога. Достоевский рисует картину общества, где утрачено представление о понятиях добра и зла. Это является весьма губительным для общества 
фактором. Герои мечутся в своем выборе между добром злом, самостоятельно неся ответственность за свой выбор и поступки. Преступление - следствие страстей, неверного выбора. На сторону зла Раскольников переходит в момент убийства, сделав неверный выбор. Одной из сторон наказания в дальнейшем будут муки совести. При этом сон, где Раскольникову снится эпизод из детства, по-моему мнению, наглядно демонстрирует, что изначальная сущность Раскольникова - добро.Просто под воздействием жизненных обстоятельств, им был сделан выбор другой сторонымедали, где понятие добра извратилось.

С проблемой добра и зла в романе, следовательно, связана проблема нравственного выбора. Для актуализации выводов романа и позиции автора будет целесообразно бы сравнить выбор, который делает Раскольников, с «проблемой вагонетки», которая предоставлена в философии утилитаризма. Суть названной проблемы состоит в том, что создаётся ситуация, когда следует принять решение о том, кто будет лишним. Представим, что на рельсах привязаны несколько человек. Заметив это тот, кто управляет вагонеткой, обязательно попытается дернуть «переключатель», чтобы увести рельсы на другой путь. Но на другом пути также оказывается человек. И что выбрать: жизнь пяти? Или жизнь одного? Будет ли выбор этически допустим? [1, c.10]. Раскольников выбирает в ситуации, когда для него есть только строго дизъюнктивный выбор: либо одно, либо другое. Он рассуждает о жизни Алёны Ивановны, помещая ее на одну чашу весов, а на другую чашу - жизнь молодых, перспективных (по мнению Родиона) людей: «С одной стороны, глупая, бессмысленная, ничтожная, злая, больная старушонка... <..> С другой стороны, молодые, свежие силы, пропадающие даром без поддержки, и это тысячами, и это всюду! Сто, тысячу добрых дел и начинаний, которые можно устроить и поправить на старухины деньги, обреченные в монастырь! Сотни, тысячи, может быть, существований, направленных на дорогу; десятки семейств, спасенных от нищеты, от разложения, от гибели, от разврата, от венерических больниц, - и всё это на ее деньги» [2]. По сути, выбор и не должен был стоять, не было изначально ситуации«вагонетки», но герой самостоятельно ее запустил, а затем только придавал ускорение своими размышлениями и взмахами топора.

Поскольку речь была о моральном выборе, а также о добре и зле, будет логично перейти к рассуждениям о совести - важной категории этического раздела. Проблема совести поднимается не просто с момента совершения одного убийства. Вместе со старухой Алёной, Родион убивает Лизавету, что поднимает проблему совести на новый уровень. Данная тема раскрывается двояко. С одной стороны, можно наблюдать все переживания героя, который мучается в бреду лихорадки, который не знает, как жить со своим поступком. С другой, он уверен, что убийство никчемной и злой старухи благой поступок, который совершается во имя благих намерений. Это своеобразный гуманитарный долг. Но такая идея является порождением извращенной совести. После убийства Лизаветы это становится очевидным фактом. Неверность данной мысли можно подтвердить также жизненным путем «двойника» Раскольникова Свидригайлова, который также запутался в себе. Одни поступки он пытается «перекрыть» другими. Он также переступает невидимую черту, за которой начинает мучать совесть, которую пытается «заглушить» посредством добрых дел. Совесть одна из причин общения Раскольникова с Сонечкой. Герой имеет потребность в общении с человеком, который представляет собой воплощение «Божьей правды», а Соне, несмотря на свою судьбу, смогла сохранить в себе черты невинного и доброго человека.

Поднимаются в романе проблемы неравенства, жертвенности, социальной справедливости. Из текста следует, что главный герой Раскольников является нравственной личностью, которая запуталась, и от этого страдает. Трудности помогают ему пройти через преломление сознания, мировоззрения, мироощущения. В этом ему 
способствует любовь Сонечки Мармеладовой, которая заставляет измениться обоих главных героев романа, позволяет им пройти через духовное возрождение. Без любви многие усилия напрасны, как видно на примере Свидригайлова.

Итак, в романе мы находим проблемы самого различного характера. Это онтологические поиски Бога, смысла жизни, верного жизненного пути; гносеологические поиски внутренней истины; аксиологические проблемы морального выбора, дихотомии добра и зла, проблема совести, общественной справедливости и неравенства, вопрос духовного возрождения, а также проблема любви. Они актуальны во все времена, поэтому актуальность романа очевидна. Это произведение обязательно к прочтению, для того, чтобы ясно и четко понимать, где находится грань того, за которой наступает постепенная потеря личности, и как вернуться в нравственное состояние тому, кто оступился.

$$
\text { *** }
$$

1. Галанина К.Э. Философия за минуту. - М.:Изд-во АСТ, 2018. - 160 с.

2. Достоевский Ф.M. Преступление и наказание. [Электронный ресурс].Режим доступа: URL: http://az.lib.ru/d/dostoewskij_f_m/text_0060.shtml (Дата обращения: 31.03.2021).

3. История создания романа «Преступление и наказание». [Электронный ресурс]. Режим доступа: URL: https://rosuchebnik.ru/material/istoriya-sozdaniya-romana-laquo-prestuplenie-i-nbsp-nakazanieraquo/ (Дата обращения: 31.03.2021).

4. Руденко А.М. Философия в схемах и таблицах: учеб. Пособие - Ростов н/Д: Феникс, 2019. - 282 с. 